\title{
KETAHANAN PANGAN RUMAH TANGGA NELAYAN TRADISIONAL DI KELURAHAN PASARMADANG KECAMATAN KOTAAGUNG KABUPATEN TANGGAMUS
}

\author{
(Food Security of the Fisherman Households in Kotaagung Sub-Distric of Tanggamus Regency)
}

Ferlia Devanda, Fembriarty Erry Prasmatiwi, Indah Nurmayasari

Jurusan Agribisnis, Fakultas Pertanian Universitas Lampung, Jl. Prof. Dr. Soemantri Brodjonegoro No. 1 Bandar Lampung 35145, e-mail: fembriarti.erry@fp.unila.ac.id

\begin{abstract}
This study aims to analyze the level of food security, factors that influence the level of food security and efforts to improve food security of fisherman households. This research is a survey conducted in coastal area Pasarmadang Village, Kotaagung Subdistrict, Tanggamus District. Respondents were 48 traditional fisherman households selected using a simple random method. Data collection was carried out in April May 2018. The level of food security was analyzed by using cross classification between the share of food expenditure and energy adequacy, the factors that influence the level of food security were analyzed by regression of ordinal logit, and efforts to improve food security were analyzed descriptive qualitatively. The results showed that most fisherman households are in the category of food insufficiency (50.00\%). The rests are in the food-resistant category (29.17\%), food vulnerable (10.42\%), and food insecurity (10.42\%). Factors that affect food security of fisherman households are the number of household members, education of housewives, and household income. Government efforts to improve food security include strengthening food availability, diversification and food security, utilizing yards, controlling food prices, fostering, providing facilities and infrastructure, PKH and Raskin programs. Meanwhile, efforts by fisherman households are to change diet, improve nutrition knowledge, and increase income by working outside the fishing business and employing family members.
\end{abstract}

Key words: cross classification, fisherman households, food security.

\section{PENDAHULUAN}

Ketahanan pangan sangat penting dalam rangka pembangunan nasional untuk membentuk sumberdaya manusia yang berkualitas yang mencerminkan kesejahteraan suatu bangsa. Definisi ketahanan pangan dalam Undang-Undang Pangan No.18 tahun 2012 adalah terpenuhinya pangan bagi negara sampai dengan perseorangan yang tercermin dari tersedianya pangan yang cukup, baik jumlah maupun mutunya, aman, beragam, bergizi, merata, dan terjangkau serta tidak bertentangan dengan agama, keyakinan, dan budaya masyarakat, untuk dapat hidup sehat, aktif, dan produktif secara berkelanjutan (Kementrian Hukum dan HAM 2012).

Provinsi Lampung mempunyai potensi yang cukup besar pada sumberdaya perikanan laut. Secara umum masyarakat pesisir berprofesi sebagai nelayan namun keadaan nelayan masih belum sejahtera. Menurut Kusnadi (2002) nelayan merupakan salah satu kelompok yang masih berada dalam kemiskinan. Lebih lanjut mengenai kemiskinan, Imron (2003) mengatakan bahwa penyebab kemiskinan yang dialami oleh nelayan adalah keterbatasan teknologi dan persaingan wilayah tangkapan. Kabupaten Tanggamus merupakan kabupaten yang menyumbang produksi perikanan laut dengan jumlah produksi mencapai 18.984 ton/tahun atau sekitar 11,74 persen pada tahun 2016 (Badan Pusat Statistik Kabupaten Tanggamus 2017). Produksi tersebut masih rendah bila dibandingkan dengan kabupaten lainnya karena masih banyaknya nelayan tradisional yang memiliki teknologi penangkapan yang sederhana.

Kecamatan Kotaagung merupakan penghasil produksi tertinggi dengan produksi sebesar $10.453,73$ ton pada tahun 2014 dan meningkat menjadi 10.668,64 ton pada tahun 2016 (Badan Pusat Statistik Kabupaten Tanggamus 2017). Namun demikian, produksi yang tinggi belum dapat menggambarkan keadaan ekonomi masyarakat nelayan. Persaingan wilayah tangkapan antara nelayan-nelayan tradisional dalam melakukan aktivitas penangkapan menyebabkan nelayan cenderung memperoleh hasil tangkapan yang sedikit dan mempengaruhi pendapatan yang diperoleh nelayan. Pendapatan merupakan faktor utama yang berpengaruh terhadap ketahanan pangan rumah tangga. 
Ketahanan pangan belum tercapai apabila masih ada masyarakat yang belum mampu mengakses pangan dengan cukup (Indriani 2015). Rumah tangga dapat mengakses pangan apabila memiliki pendapatan yang cukup. Sementara itu, pendapatan rendah akan mencerminkan adanya persediaan pangan yang kurang cukup dan daya beli yang rendah. Harga pangan yang cenderung meningkat sehingga sulit untuk menjangkau ketersediaan pangan dalam jumlah yang cukup, aman, dan bergizi (Purwaningsih 2008). Berdasarkan permasalahan tersebut perlu diketahui bagaimana tingkat ketahanan pangan rumah tangga nelayan tradisional di Kelurahan Pasarmadang. Penelitian ini bertujuan menganalisis ketahanan pangan rumah tangga nelayan tradisional dan faktor-faktor yang memengaruhi serta upaya untuk meningkatkan ketahanan pangan rumah tangga nelayan tradisional.

\section{METODE PENELITIAN}

Metode penelitian yang digunakan pada penelitian ini adalah survei. Penelitian ini dilakukan di Kelurahan Pasarmadang Kecamatan Kotaagung Kabupaten Tanggamus. Lokasi penelitian diambil secara sengaja (purposive) dengan pertimbangan bahwa wilayah tersebut berada di pinggir pesisir yang mayoritas penduduknya berprofesi sebagai nelayan. Populasi dalam penelitian ini berjumlah 130 rumah tangga nelayan yang terdiri dari 80 rumah tangga jaring rampus dan 50 rumah tangga pancing. Sampel pada penelitian ini berjumlah 48 rumah tangga nelayan yang terbagi menjadi 30 rumah tangga dengan alat tangkap jaring rampus dan 18 rumah tangga dengan alat tangkap pancing. Pengambilan sampel dilakukan menggunakan metode acak sederhana (Sugiarto, Sunaryanto dan Oetomo 2003). Penentuan sampel dilakukan dengan metode proportional random sampling. Waktu pengumpulan data dilakukan pada bulan Apri-Mei 2018.

Data yang digunakan pada penelitian ini yaitu data primer dan data sekunder. Data primer diperoleh dari wawancara langsung dengan rumah tangga nelayan tradisional dan pengurus instansi pemerintah menggunakan kuesioner. Data primer yang dikumpulkan antara lain pendapatan rumah tangga, pengeluaran rumah tangga, konsumsi recall rumah tangga, upaya-upaya rumah tangga maupun upaya-upaya dari instansi-instansi pemerintah daerah tersebut dalam meningkatkan ketahanan pangan. Data sekunder diperoleh dari berbagai dinas atau instansi terkait seperti Dinas Ketahanan Pangan Kabupaten Tanggamus (data konsumsi pangan), Dinas Kelautan dan Perikanan Kabupaten Tanggamus (produksi perikanan laut), Badan Pusat Statistik Kabupaten Tanggamus, serta literatur-literatur. Metode pengambilan data konsumsi pangan rumah tangga menggunakan metode recall selama $2 \times 24$ jam dengan hari yang tidak berurutan.

Ketahanan pangan rumah tangga nelayan tradisional dianalisis dengan menggunakan indikator klasifikasi silang antara pangsa pengeluaran pangan dengan kecukupan energi yang mengacu pada Johnsson dan Toole (1991) dalam Indriani (2015). Tingkat ketahanan pangan dengan indikator tersebut diperjelas dalam Tabel 1.

Pangsa pengeluaran pangan dihitung dengan rumus sebagai berikut:

$\mathrm{PPP}=\frac{\mathrm{PP}}{\mathrm{TP}} \times 100 \%$

Keterangan :

PPP = Pangsa pengeluaran pangan (\%)

$\mathrm{PP} \quad=$ Pengeluaran pangan (Rp/bulan)

$\mathrm{TP}=$ Total pengeluaran rumah tangga (pangan dan nonpangan) ( $\mathrm{Rp} /$ bulan)

Data konsumsi pangan rumah tangga dihitung dengan rumus sebagai berikut:

$\mathrm{KErt}=\frac{\mathrm{BPj}}{100} \mathrm{X} \frac{\mathrm{bdd}}{100} \mathrm{X} \mathrm{KEj}$

Keterangan:

Kert $=$ Konsumsi energi rill rumah tangga (kkal)

$\mathrm{BPj}=$ Berat makanan atau pangan $-\mathrm{j}$ yang dikonsumsi (gram)

Bdd = Bagian yang dapat dimakan ( dalam \% atau gram dari 100 gram pangan atau makanan-j)

$\mathrm{KEj}=$ Kandungan energi dari pangan $-\mathrm{j}$ atau makanan yang dikonsumsi (kal)

Tabel 1. Tingkat Ketahanan Pangan Keluarga

\begin{tabular}{ccc}
$\begin{array}{c}\text { Konsumsi } \\
\text { energi }\end{array}$ & Pangsa pengeluaran pangan \\
\cline { 2 - 3 } & Rendah $(<60 \%)$ & Tinggi $(\geq 60 \%)$ \\
\hline $\begin{array}{c}\text { Cukup } \\
(>80 \%) \\
\begin{array}{c}\text { Kurang } \\
(\leq 80 \%)\end{array}\end{array}$ & Tahan Pangan & Rentan Pangan \\
\hline Sumber: Johnsson and Toole (1991) dalam Indriani $(2015)$
\end{tabular}

Sumber: Johnsson and Toole (1991) dalam Indriani (2015) 
Angka Kecukupan Energi (AKE) dapat dihitung dengan rumus sebagai berikut:

$\mathrm{AKE}=\frac{\mathrm{BB}}{\mathrm{BB} \text { Standar }} \times \mathrm{AKE}$ tabel

Keterangan:

$\begin{array}{ll}\mathrm{AKE} & =\text { Angka kecukupan energi } \\ \mathrm{BB} & =\text { Berat badan aktual }(\mathrm{kg}) \\ \mathrm{BB} \text { standar } & =\text { Berat standar }(\mathrm{kg}) \\ \mathrm{AKG} \text { tabel } & =\text { Angka kecukupan zat gizi dalam } \\ & \text { tabel kecukupan gizi yang } \\ & \text { dianjurkan }\end{array}$

Menurut Indriani (2015) untuk menghitung Tingkat Kecukupan Energi (TKE) dapat digunakan rumus sebagai berikut:

$\mathrm{TKE}=\frac{\text { Asupan zat gizi }}{\mathrm{AKE}} \times 100 \%$

Keterangan:

TKE $=$ Tingkat kecukupan energi

Asupan zat gizi $=$ Asupan zat gizi energi dalam makanan

AKE $=$ Angka kecukupan energi

Tingkat Kecukupan Protein (TKP) dapat dihitung dengan rumus sebagai berikut:

$\mathrm{TKP}=\frac{\text { Asupan zat gizi }}{\mathrm{AKP}} \times 100 \%$

Keterangan:

$\begin{array}{ll}\text { TKP } & =\text { Tingkat kecukupan protein } \\ \text { Asupan zat gizi } & =\begin{array}{l}\text { Asupan zat gizi energi } \\ \text { dalam makanan }\end{array} \\ \text { AKP } & =\text { Angka kecukupan protein }\end{array}$

Analisis faktor-faktor yang memengaruhi tingkat ketahanan pangan rumah tangga nelayan tradisional di Kelurahan Pasarmadang diuji menggunakan analisis regresi ordinal logit. Menurut Pumami, Sukarsa dan Gandhiadi (2015) regresi ordinal logistik merupakan alat statistika yang memanfaatkan hubungan antara dua atau lebih variabel sehingga salah satu variabel bisa diramalkan dari variabel lain. Variabel respon lebih dari dua kategori berskala ordinal dan variabel predikator berupa data kategori dan/atau kontinyu dengan dua variabel atau lebih.

Signifikansi dari tiap variabel independen terhadap variabel dependennya dapat dilihat dari statistik uji $L R$ dan uji Wald. Dalam pengujian serentak, uji signifikansi model dapat menggunakan LikelihoodRatio test. Estimasi model logit menggunakan uji
Likelihood Ratio (LR) untuk mengetahui tingkat pengaruh seluruh variabel independen secara bersama-sama terhadap variabel dependen. Untuk menguji masing-masing variabel independen terhadap variable independen secara individu yang terdapat dalam model dapat dilakukan dengan uji Wald. Uji Goodness of fit untuk mengetahui seberapa baik model dalam menjelaskan hubungan antara variabel dependen dengan variabel independennya.

Persamaan regresi dinyatakan sebagai berikut:

$$
\begin{aligned}
\mathrm{Li}= & \operatorname{Ln}\left[\frac{\mathrm{Pi}}{1-\mathrm{Pi}}\right]=\mathrm{Zi}=\beta+\beta_{1} \mathrm{X}_{1}+\beta_{2} \mathrm{X}_{2}+\beta_{3} \mathrm{X}_{3}+\beta_{4} \mathrm{X}_{4} \\
& \beta_{5} \mathrm{X}_{5}+\beta_{6} \mathrm{X}_{6}+\beta_{7} \mathrm{X}_{7}+\beta_{8} \mathrm{X}_{8}+\beta_{9} \mathrm{D}+\mathrm{e} \ldots \ldots \ldots(6)
\end{aligned}
$$

Keterangan:

$\mathrm{Li}=$ Probabilitas $\mathrm{L} 1=\mathrm{Li}(\mathrm{Y}=4)$ untuk rumah tangga tahan pangan

Probabilitas $\mathrm{L} 2=\mathrm{Li}(\mathrm{Y}=3)$ untuk rumah tangga kurang pangan

Probabilitas L3 = Li $(\mathrm{Y}=2)$ untuk rumah tangga rentan pangan

Probabilitas L4 = Li $(\mathrm{Y}=1)$ untuk rumah tangga rawan pangan

$\mathrm{Pi} \quad=$ Peluang untuk menentukan tingkat ketahanan pangan bila Xi diketahui

$\mathrm{B}=$ Intersep

$\beta 1-\beta 6=$ Koefisien regresi parameter $(\mathrm{i}=1,2,3,4,5,6)$

$\mathrm{X}_{1} \quad=$ Besar anggota rumah tangga (orang)

$\mathrm{X}_{2} \quad=$ Pendidikan ibu rumah tangga (tahun)

$\mathrm{X}_{3} \quad=$ Pendapatan rumah tangga (Rp/bulan)

$\mathrm{X}_{4} \quad=$ Harga beras $(\mathrm{Rp} / \mathrm{kg})$

$\mathrm{X}_{5} \quad=$ Harga gula $(\mathrm{Rp} / \mathrm{kg})$

$\mathrm{X}_{6} \quad=$ Harga minyak $(\mathrm{Rp} / \mathrm{kg})$

$\mathrm{X}_{7} \quad=$ Harga tepung terigu $(\mathrm{Rp} / \mathrm{kg})$

$\mathrm{X}_{8} \quad=$ Harga tempe $(\mathrm{Rp} / \mathrm{kg})$

$\mathrm{D} \quad=$ Dummy alat tangkap nilai $1=$ jaring rampus nilai $2=$ pancing

e $\quad=$ Error term

Analisis untuk mengetahui upaya-upaya meningkatkan ketahanan pangan rumah tangga nelayan tradisional dilakukan dengan analisis deskriptif. Langkah-langkah analisis yang digunakan adalah menelaah masalah terkait persoalan ketahanan pangan rumah tangga nelayan lalu mencari tahu solusi yang diterapkan untuk menangani permasalahan melalui programprogram yang pernah/sedang/akan dilakukan untuk meningkatkan ketahanan pangan serta partsipasi rumah tangga nelayan untuk meningkatkan ketahanan pangan. 


\section{HASIL DAN PEMBAHASAN}

\section{Karakteristik Responden}

Usia responden antara 26 sampai dengan 58 tahun. Mayoritas usia kepala dan ibu rumah tangga 48-58 tahun sehingga dapat dikatakan termasuk dalam usia produktif. Tingkat pendidikan dapat memengaruhi cara berfikir dan bertindak seseorang. Mayoritas tingkat pendidikan kepala maupun ibu rumah tangga adalah Sekolah Dasar (SD) yang dapat dikatakan pendidikanya masih rendah. Setiap pertambahan usia akan meningkatkan pengalaman seseorang dalam bekerja. Rata-rata pengalaman melaut nelayan yaitu 26 tahun. Rata-rata jumlah anggota rumah tangga adalah 4 orang. Pekerjaan utama kepala rumah tangga nelayan adalah nelayan. Pekerjaan sampingan yang dilakukan kepala rumah tangga jaring rampus maupun pancing antara lain sebagai ojek, kuli bangunan dan buruh pasar. Adapun beberapa ibu rumah tangga jaring rampus maupun pancing bekerja sebagai pengrajin ikan asin, buruh cuci dan buruh dagang.

Pendapatan rumah tangga nelayan berasal dari kegiatan usaha ikan tangkap, kegiatan di luar usaha ikan tangkap, nonperikanan dan bantuan pemerintah. Sebagian besar pendapatan rumah tangga nelayan berasal dari pendapatan usaha ikan tangkap . Rata-rata total pendapatan rumah tangga jaring rampus sebesar Rp37.635.666,67 per tahun atau Rp3.136.305,56 per bulan dan pendapatan rumah tangga pancing sebesar Rp36.369.388,89 per tahun atau Rp3.030.782,41 per bulan. Distribusi pendapatan rumah tangga nelayan jaring rampus dan pancing di Kelurahan Pasarmadang Tahun 2018 dapat dilihat pada Tabel 2.

Tabel 2. Distribusi pendapatan rumah tangga nelayan jaring rampus dan pancing di Kelurahan Pasarmadang Tahun 2018

\begin{tabular}{|c|c|c|c|}
\hline No & $\begin{array}{c}\text { Sumber } \\
\text { Pendapatan } \\
\text { (Rp/tahun) }\end{array}$ & $\begin{array}{c}\text { Pendapatan } \\
\text { RMH Jaring } \\
\text { (Rp/tahun) }\end{array}$ & $\begin{array}{l}\text { Pendapatan } \\
\text { RMH Pancing } \\
\text { (Rp/tahun) }\end{array}$ \\
\hline 1 & $\begin{array}{l}\text { Pendapatan } \\
\text { usaha ikan } \\
\text { tangkap }\end{array}$ & $35.489 .000,00$ & $30.580 .500,00$ \\
\hline 2 & $\begin{array}{l}\text { Pendapatan di } \\
\text { luar usaha ikan } \\
\text { tangkap }\end{array}$ & $400.000,00$ & $666.666,67$ \\
\hline 3 & $\begin{array}{l}\text { Pendapatan non } \\
\text { perikanan }\end{array}$ & $1.580 .000,00$ & $2.866 .666,67$ \\
\hline 4 & $\begin{array}{l}\text { Bantuan } \\
\text { pemerintah }\end{array}$ & $166.666,67$ & $255.555,56$ \\
\hline & Jumlah & $37.635 .666,67$ & $36.369 .388,89$ \\
\hline
\end{tabular}

\section{Ketahanan Pangan Rumah Tangga Ketersediaan pangan}

Ketersediaan pangan suatu rumah tangga merupakan jumlah pangan yang tersedia dalam rumah tangga dilihat dari produksi pangan pokok (beras), pangan yang tidak mencukupi dan kepemilikan cadangan pangan. Rumah tangga nelayan sangat bergantung pada pasokan bahan pangan pokok yang berasal dari luar. Selain memperoleh pangan pokok melalui pembelian, sebagian rumah tangga juga memperoleh pangan pokok melaui bantuan pemerintah. Persediaan beras dari bantuan pemerintah yaitu rastra (beras sejahtera) diberikan kepada rumah tangga yang kurang mampu.

Seluruh rumah tangga nelayan tidak memproduksi pangan pokok berupa beras. Ketersediaan rata-rata pangan pokok beras rumah tangga selama sebulan sebesar $35,73 \mathrm{~kg}$ dengan rincian: $31,90 \mathrm{~kg}$ berasal dari pembelian dan $3,83 \mathrm{~kg}$ dari bantuan pemerintah. Rumah tangga nelayan tidak memiliki cadangan pangan pokok berupa beras yang disiapkan untuk kebutuhan konsumsi yang akan datang. Selain pangan pokok, rumah tangga memenuhi kebutuhan pangan tambahan lainnya seperti lauk pauk, sayuran atau buah-buahan. Sebesar 89,58 persen rumah tangga menjawab pangan buah-buahan merupakan pangan yang sulit tercukupi dan sisanya sebesar 10,42 persen menjawab pangan yang tidak mencukupi yaitu lauk-pauk.

\section{Distribusi (akses) pangan}

Distribusi (akses) pangan ditunjukkan dengan kemampuan memiliki sumber daya secara fisik maupun ekonomi untuk mendapatkan bahan pangan. Seluruh rumah tangga nelayan di Kelurahan Pasarmadang memperoleh bahan pangan seperti beras, tepung terigu, minyak dan bahan pangan lainnya melalui pembelian. Rumah tangga nelayan tidak mempunyai lahan pertanian dan tidak memiliki kemampuan dalam bertani sehingga tidak dapat memproduksi pangan secara langsung. Pangan ikan merupakan satu-satunya bahan pangan yang diperoleh melalui produksi sendiri. Pasokan pangan di wilayah Kelurahan Pasarmadang khususnya di pasar dan di warung/kios selalu tersedia mulai dari bahan pangan pokok, lauk-pauk, sayuran dan bahan pangan lainnya. Namun, walaupun bahan pangan selalu tersedia belum tentu setiap rumah tangga dapat mengakses pangan dengan baik. Setiap rumah tangga memiliki tingkat pendapatan yang 
berbeda-beda. Rumah tangga yang memiliki pendapatan tinggi memungkinkan akan mengakses pangan dengan mudah namun rumah tangga dengan pendapatan rendah akan kesulitan dalam mengakses pangan.

Harga pangan yang stabil di Kelurahan Pasarmadang mengindikasikan bahwa sistem distribusi pangan relatif baik. Hal ini juga didukung karena adanya infrastruktur yang memadai dan jalan-jalan yang sudah beraspal sehingga proses pendistribusian pangan berjalan lancar. Untuk mengakses pangan, rumah tangga nelayan menempuh jarak yang cukup dekat sekitar $0,52 \mathrm{~km}$ dari rumah menuju pasar terdekat.

\section{Konsumsi Pangan}

Konsumsi pangan menjamin setiap rumah tangga mengonsumsi pangan dalam jumlah yang cukup, baik dalam kuantitas maupun kualitas. Seluruh rumah tangga nelayan mengatakan tidak mengonsumsi makanan beragam, bergizi dan berimbang, hal ini dikarenakan bahan makanan berupa buah-buahan dan susu belum tercukupi dengan baik untuk melengkapi asupan makanan yang dikonsumsi. Rumah tangga nelayan mengonsumsi makanan dengan frekuensi makan dalam sehari tiga kali dengan volume makan yang cukup terutama nasi sebagai makanan pokok.

Tingkat kecukupan energi maupun protein diperoleh dari perhitungan konsumsi energi/protein riil rumah tangga dibagi dengan angka kecukupan energi/protein yang dianjurkan bagi rumah tangga. Rata-rata asupan energi rumah tangga nelayan adalah 7074,76 kkal/hari dan rata-rata konsumsi protein rumah tangga sebanyak 231,38 gram/hari. Jika dilihat dari konsumsi energi per kapita sebesar $1768,70 \mathrm{kkal} / \mathrm{kapita} / \mathrm{hari}$ masih dibawah anjuran syarat kecukupan energi dalam Widyakarya Nasional Pangan dan Gizi (WNPG) X Tahun 2012 yaitu sebesar $2150 \mathrm{kkal} /$ perkapita/hari (LIPI 2012). Konsumsi energi yang kurang karena kebiasaan makan rumah tangga yang belum memenuhi kualitas maupun kuantitas dengan baik. Konsumsi energi terbesar berasal dari golongan pangan padipadian. Rata-rata konsumsi energi dan protein rumah tangga nelayan di Kelurahan Pasarmadang dapat dilihat pada Tabel 3. Adapun sebaran rumah tangga berdasarkan tingkat kecukupan energi maupun protein dapat dilihat pada Tabel 4 dan Tabel 5.
Tabel 3. Rata-rata konsumsi energi dan protein rumah tangga nelayan di Kelurahan Pasarmadang

\begin{tabular}{|c|c|c|c|c|}
\hline \multirow{2}{*}{$\begin{array}{c}\text { Golongan } \\
\text { pangan }\end{array}$} & \multicolumn{2}{|c|}{$\begin{array}{c}\text { Rata-rata } \\
\text { Konsumsi Energi }\end{array}$} & \multicolumn{2}{|c|}{$\begin{array}{c}\text { Rata-rata } \\
\text { Konsumsi Protein }\end{array}$} \\
\hline & kkal & $(\%)$ & gram & $(\%)$ \\
\hline Padi-padian & $3.834,72$ & 54,20 & 71,30 & 31,84 \\
\hline $\begin{array}{l}\text { Umbi- } \\
\text { umbian }\end{array}$ & 49,26 & 0,70 & 0,38 & 0,17 \\
\hline Hewani & 619,43 & 8,76 & 97,78 & 43,66 \\
\hline $\begin{array}{l}\text { Kacang- } \\
\text { kacangan }\end{array}$ & 348,73 & 4,93 & 26,14 & 11,67 \\
\hline $\begin{array}{l}\text { Sayur dan } \\
\text { buah }\end{array}$ & 240,37 & 3,40 & 10,01 & 4,47 \\
\hline Gula & 355,53 & 5,03 & 1,98 & 0,88 \\
\hline Minyak & $1.324,56$ & 18,72 & 1,51 & 0,67 \\
\hline $\begin{array}{l}\text { Buah biji } \\
\text { berminyak }\end{array}$ & 19,06 & 0,27 & 0,28 & 0,13 \\
\hline Lain-lain & 283,09 & 4,00 & 14,57 & 6,50 \\
\hline Total & $7.074,76$ & 100,00 & 223,95 & 100,00 \\
\hline AKE/AKP & $9.064,90$ & & 231,38 & \\
\hline TKE/TKP & & 78,09 & & 96,21 \\
\hline
\end{tabular}

Tingkat kecukupan energi dibagi menjadi kategori cukup (>80\%) dan kurang ( $\leq 80 \%)$. Menurut Yuliana, Zakaria dan Adawiyah (2013) tingkat kecukupan protein dibagi menjadi kategori baik (>80\%), cukup (70-79\%), sedang (60-69\%) dan buruk $(<60 \%)$. Berdasarkan Tabel 6 dapat dijelaskan bahwa sebagian besar rumah tangga nelayan memiliki tingkat kecukupan energi yang kurang yaitu sebesar 60,42 persen dan pada Tabel 7 dijelaskan bahwa sebagian besar rumah tangga atau sebesar 87,50 persen rumah tangga memiliki tingkat kecukupan protein $\geq 80 \%$ yang baik. Tingkat kecukupan protein yang baik dipengaruhi oleh ketersediaan protein yang berasal dari ikan.

Tabel 4. Sebaran rumah tangga berdasarkan tingkat kecukupan energi

\begin{tabular}{ccccc}
\hline No & $\begin{array}{c}\text { Tingkat } \\
\text { kecukupan } \\
\text { energi }\end{array}$ & Kategori & $\begin{array}{c}\text { Jumlah } \\
\text { (n) }\end{array}$ & $(\%)$ \\
\hline 1 & $>80 \%$ & Cukup & 19 & 39,58 \\
2 & $\leq 80 \%$ & Kurang & 29 & 60,42 \\
\hline Jumlah & & & 48 & 100,00 \\
\hline
\end{tabular}

Tabel 5. Sebaran rumah tangga berdasarkan tingkat kecukupan protein

\begin{tabular}{cllrr}
\hline No & $\begin{array}{c}\text { Tingkat } \\
\text { kecukupan } \\
\text { protein }\end{array}$ & Kategori & $\begin{array}{c}\text { Jumlah } \\
(\mathrm{n})\end{array}$ & $(\%)$ \\
\hline 1 & $>80 \%$ & Baik & 42 & 87,50 \\
2 & $70-78 \%$ & Cukup & 5 & 12,50 \\
3 & $60-69 \%$ & Sedang & 1 & 2,08 \\
4 & $<60 \%$ & Buruk & 0 & 0 \\
\hline Jumlah & & & 48 & 100,00 \\
\hline
\end{tabular}




\section{Ketahanan Pangan Rumah Tangga Nelayan}

Ketahanan pangan rumah tangga nelayan dianalisis menggunakan klasifikasi silang antara pangsa pengeluaran pangan rumah tangga dengan kecukupan energi menurut Johnsson Toole (1991) dalam Indriani (2015). Pengeluaran total rumah tangga terdiri dari pengeluaran pangan maupun nonpangan. Pengeluaran pangan terbesar dibelanjakan untuk kebutuhan pangan pokok yaitu beras sebesar Rp389.479,17 atau sebesar 32,24 persen. Pengeluaran pangan setelah beras yaitu pengeluaran lauk-pauk sebesar Rp314.562,59 atau sebesar 26,03 persen. Pengeluaran nonpangan didominasi oleh pengeluaran untuk kebutuhan belanja rokok sebesar Rp376.770,83 atau sebesar 38,72 persen lalu diikuti pengeluaran untuk uang saku sebesar Rp99.583,33 atau sebesar 10,24 persen. Rata-rata rumah tangga nelayan mempunyai kebiasaan mengonsumsi rokok setiap hari. Rata-rata pengeluaran total rumah tangga nelayan di Kelurahan Pasarmadang dapat dilihat pada Tabel 6 dan sebaran rumah tangga berdasarkan kategori pangsa pengeluaran pangan dapat dilihat pada Tabel 7.

Tabel 6. Rata-rata pengeluaran total rumah tangga nelayan di Kelurahan Pasarmadang

\begin{tabular}{|c|c|c|c|}
\hline No & Jenis Pengeluaran & Jumlah (Rp) & $(\%)$ \\
\hline \multicolumn{4}{|c|}{ Pangan } \\
\hline \multirow[t]{3}{*}{1} & Pangan pokok & & \\
\hline & Beras & $389.479,17$ & 32,24 \\
\hline & Bukan beras & $29.575,52$ & 2,45 \\
\hline 2 & Lauk-pauk & $314.562,59$ & 26,03 \\
\hline 3 & Kacang-kacangan & $3.437,50$ & 0,28 \\
\hline 4 & Sayuran & $136.374,48$ & 11,29 \\
\hline 5 & Buah-buahan & $14.437,50$ & 1,19 \\
\hline 6 & Lemak & $68.007,81$ & 5,63 \\
\hline 7 & Makanan jajanan & $30.937,50$ & 2,56 \\
\hline 8 & Minuman & $85.299,48$ & 7,06 \\
\hline 9 & Bumbu & $136.119,79$ & 11,27 \\
\hline Tota & engeluaran pangan & $1.208 .231,34$ & 55,39 \\
\hline \multicolumn{4}{|c|}{ Nonpangan } \\
\hline 10 & Listrik & $90.312,50$ & 9,28 \\
\hline 11 & Gas & $65.833,33$ & 6,77 \\
\hline 12 & Bahan bakar & $22.354,17$ & 2,30 \\
\hline 13 & Rokok & $376.770,83$ & 38,72 \\
\hline 14 & Uang saku & $99.583,33$ & 10,24 \\
\hline 15 & SPP & $68.854,17$ & 7,08 \\
\hline 16 & Pakaian & $53.993,06$ & 5,55 \\
\hline 17 & Kesehatan & $12.335,07$ & 1,27 \\
\hline 18 & Arisan & $46.875,00$ & 4,82 \\
\hline 19 & Komunikasi & $43.500,00$ & 4,47 \\
\hline 20 & Sabun & $74.552,08$ & 7,66 \\
\hline 21 & Kecantikan & $10.833,33$ & 1,11 \\
\hline 22 & Sumbangan & $7.144,10$ & 0,73 \\
\hline \multicolumn{2}{|c|}{ Total pengeluaran nonpangan } & $972.940,97$ & 44,61 \\
\hline \multicolumn{2}{|c|}{ Total pengeluaran rumah tangga } & 2.181.172,31 & 100,00 \\
\hline
\end{tabular}

Tabel 7. Sebaran rumah tangga berdasarkan kategori pangsa pengeluaran pangan

\begin{tabular}{cccc}
\hline $\begin{array}{c}\text { Pangsa } \\
\text { pengeluaran } \\
\text { pangan }\end{array}$ & $\begin{array}{c}\text { Kategori pangsa } \\
\text { pengeluaran } \\
\text { pangan }\end{array}$ & $\begin{array}{c}\text { Jumlah } \\
(\mathrm{n})\end{array}$ & $(\%)$ \\
\hline$<60 \%$ & rendah & 38 & 79,16 \\
$\geq 60 \%$ & tinggi & 10 & 20,83 \\
\hline
\end{tabular}

Pada Tabel 6 dapat dijelaskan bahwa rata-rata pengeluaran total rumah tangga nelayan di Kelurahan Pasarmadang sebesar Rp2.181.172,31 yang terdiri dari pengeluaran pangan sebesar Rp1.208.231,34 dan pengeluaran nonpangan sebesar Rp974.940,97. Adapun pada Tabel 7 dijelaskan bahwa sebagian besar rumah tangga nelayan memiliki pangsa pengeluaran yang rendah yaitu sebesar 79,16 persen. Pengelompokkan rumah tangga berdasarkan tingkat ketahanan pangan dapat dilihat pada Tabel 8 .

Pada Tabel 8 dapat dijelaskan bahwa sebagian besar rumah tangga nelayan berada pada kondisi kurang pangan dengan pangsa pengeluaran pangan yang rendah sebesar 53,04 persen dan tingkat kecukupan energi pangan yang kurang sebesar 74,76 persen. Pangsa pengeluaran pangan yang rendah mengindikasikan pendapatan yang diperoleh sudah cukup tinggi (Ilham dan Sinaga 2007). Pendapatan rumah tangga nelayan jaring rampus sebesar Rp3.136.305,56 per bulan dan rumah tangga pancing sebesar Rp3.030.782,41 per bulan telah melebihi UMP Lampung sebesar Rp2.241.269,00. Namun, pendapatan yang diperoleh belum dapat dialokasikan dengan baik untuk belanja pangan sehingga kecukupan energi belum terpenuhi dengan baik. Dengan demikian, rumah tangga nelayan yang kurang pangan perlu meningkatkan pengetahuan mengenai gizi yang baik dan merealokasikan pengeluaran pangan yang lebih baik lagi untuk memenuhi kebutuhan pangan secara kuantitas maupun kualitas sehingga dapat mencapai tahan pangan.

Tabel 8. Pengelompokkan rumah tangga berdasarkan tingkat ketahanan pangan

\begin{tabular}{lcccc}
\hline $\begin{array}{c}\text { Tingkat Ketahanan } \\
\text { Pangan }\end{array}$ & $\begin{array}{c}\text { PPP } \\
(\%)\end{array}$ & $\begin{array}{c}\text { TKE } \\
(\%)\end{array}$ & $\begin{array}{c}\text { Jumlah } \\
(\mathrm{n})\end{array}$ & $(\%)$ \\
\hline Tahan pangan & 53,42 & 82,91 & 14 & 29,17 \\
Kurang pangan & 53,04 & 74,76 & 24 & 50,00 \\
Rentan pangan & 62,77 & 83,22 & 5 & 10,42 \\
Rawan Pangan & 63,75 & 76,20 & 5 & 10,42 \\
\hline
\end{tabular}


Sementara itu, rumah tangga tahan pangan menempati posisi kedua dengan pangsa pengeluaran pangan rendah sebesar 53,42 persen dan tingkat kecukupan energi cukup sebesar 82,91 persen. Pangsa pengeluaran yang rendah menggambarkan pendapatan yang diperoleh tinggi dan tingkat konsumsi rumah tangga nelayan cukup. Pangsa pengeluaran pangan rumah tangga rentan pangan sebesar 62,77 persen dan kecukupan energi sebesar 83,22 persen. Pendapatan yang diterima rumah tangga rentan pangan masih diprioritaskan untuk kebutuhan belanja pangan daripada nonpangan namun rumah tangga rentan pangan dalam mengonsumsi energi dapat dikatakan cukup dikarenakan rumah tangga rentan pangan mengonsumsi pangan karbohidrat tinggi yang berasal dari pangan pokok yaitu beras. Sementara itu, kondisi rumah tangga rawan pangan diindikasikan dengan pangsa pengeluaran pangan yang tinggi sebesar 63,75 persen dan kecukupan energi kurang sebesar 76,20 persen. Bagi rumah tangga rawan pangan diperlukan untuk meningkatkan pendapatan rumah tangga dan mempelajari pengetahuan tentang gizi.

\section{Faktor-Faktor Yang Memengaruhi Ketahanan Pangan Rumah Tangga}

Hipotesis yang digunakan adalah diduga faktorfaktor yang memengaruhi ketahanan pangan rumah tangga nelayan di Kelurahan Pasarmadang adalah jumlah anggota rumah tangga $\left(X_{1}\right)$, pendidikan ibu rumah tangga $\left(X_{2}\right)$, pendapatan rumah tangga $\left(X_{3}\right)$, harga beras $\left(X_{4}\right)$, harga gula $\left(X_{5}\right)$, harga minyak $\left(X_{6}\right)$, harga tepung terigu $\left(\mathrm{X}_{7}\right)$, harga tempe $\left(\mathrm{X}_{8}\right)$ dan jenis alat tangkap(dummy). Hasil analisis regresi ordinal logit dapat dilihat pada Tabel 9.

Nilai Pseudo R-squared sebesar 0,4318 menjelaskan bahwa 43,18 persen variasi probabilitas tingkat ketahanan pangan rumah tangga nelayan dapat dijelaskan oleh variasi variable independen $X_{1}$ sampai dengan $X_{8}$. Nilai Prob (LR statistic) yaitu sebesar 0,0000 menjelaskan bahwa secara bersama-sama variabel jumlah anggota rumah tangga, pendidikan ibu rumah tangga, pendapatan rumah tangga, harga beras, harga gula, harga minyak, harga tepung terigu,harga tempe dan jenis alat tangkap berpengaruh terhadap peluang rumah tangga untuk meningkatkan ketahanan pangan.
Tabel 9. Hasil regresi ordinal logit faktor-faktor yang memengaruhi ketahanan pangan

\begin{tabular}{|c|c|c|c|c|}
\hline Variable & Coef & Std. Error & Z-Stat & Prob \\
\hline $\begin{array}{l}\text { Jumlah anggota rumah } \\
\text { tangga(X1) }\end{array}$ & $-0,9027 * *$ & 0,3994 & $-2,2598$ & 0,0238 \\
\hline $\begin{array}{l}\text { Pendidikan ibu rumah } \\
\text { tangga(X2) }\end{array}$ & $1,5232 * * *$ & 0,3867 & 3,9382 & 0,0001 \\
\hline $\begin{array}{l}\text { Pendapatan rumah } \\
\text { tangga(X3) }\end{array}$ & $1,44 \mathrm{E}-* *$ & $7,25 \mathrm{E}-$ & 1,9829 & 0,0474 \\
\hline Harga beras(X4) & $-0,0004$ & 0,0004 & $-1,-0989$ & 0,2718 \\
\hline Harga gula(X5) & $-0,0007$ & 0,0010 & $-0,7307$ & 0,4650 \\
\hline Harga minyak(X6) & $-0,0010$ & 0,0008 & $-1,1914$ & 0,2335 \\
\hline Harga tepung terigu(X7) & $-0,0001$ & 0,0008 & $-0,2448$ & 0,8066 \\
\hline Harga tempe(X8) & 0,0003 & 0,0005 & 0,7622 & 0,4459 \\
\hline Jenis alat tangkap (D) & $-1,1694$ & 0,9285 & $-1,2593$ & 0,2079 \\
\hline LIMIT_2:C(10) & $-17,6302$ & 17,2579 & $-1,0215$ & 0,3070 \\
\hline LIMIT_3:C(11) & $-16,3657$ & 17,2035 & $-0,9513$ & 0,3415 \\
\hline LIMIT_4:C(12) & $-11,2298$ & 17,0830 & $-0,6573$ & 0,5109 \\
\hline Pseudo R-squared & & & & 0,4318 \\
\hline LR statistic & & & & 48,8051 \\
\hline Prob(LR statistic) & & & & 0,0000 \\
\hline
\end{tabular}

Variabel jumlah anggota rumah tangga berpengaruh negatif terhadap peluang rumah tangga untuk mencapai ketahanan pangan dengan nilai probability sebesar 0,0238 . Hasil penelitian ini sejalan dengan penelitian yang dilakukan oleh Hernanda, Indriani dan Listiana (2013) yang menyatakan jumlah anggota rumah tangga berpengaruh negatif terhadap ketahahan pangan.

Pendidikan ibu rumah tangga berpengaruh positif terhadap peluang rumah tangga untuk mencapai ketahanan pangan dengan nilai probability sebesar 0,0001. Semakin tinggi tingkat pendidikan ibu rumah tangga akan meningkatkan ketahanan pangan. Hasil penelitian ini sejalan dengan penelitian yang dilakukan oleh Delly, Prasmatiwi dan Prayitno (2019) yang menyatakan bahwa pendidikan ibu rumah tangga mempunyai pengaruh positif terhadap ketahanan pangan. Pendapatan rumah tangga berpengaruh terhadap peluang rumah tangga untuk mencapai ketahanan pangan dengan nilai probability sebesar 0,0474 . Hasil penelitian tersebut sejalan dengan penelitian yang dilakukan oleh Anggraini, Zakaria dan Prasmatiwi (2014) yang menyatakan bahwa pendapatan berpengaruh positif terhadap ketahanan pangan rumah tangga.

\section{Upaya Meningkatkan Ketahanan Pangan}

Upaya-upaya meningkatkan ketahanan pangan dilakukan oleh pemerintah maupun rumah tangga. Upaya-upaya pemerintah meningkatkan ketahanan pangan meliputi pemantapan ketersediaan pangan, penganekaragaman, keamanan pangan, 
pemanfaatan pekarangan, pengendalian harga pangan, pembinaan, bantuan sarana dan prasarana, program PKH dan raskin. Program-program tersebut telah ada dan masih diterapkan sampai saat ini. Upaya-upaya rumah tangga untuk meningkatkan ketahanan pangan yakni sebesar 31,25 persen merubah pola makan dengan cara mengurangi porsi makan atau mengubah kualitas pangan yang akan dikonsumsi, sebesar 27,08 persen melakukan pekerjaan di luar usaha tangkap, sebesar 25,00 persen berhutang kepada saudara maupun tetangga dan sebesar 20,83 persen memperkerjakan anggota rumah tangga.

\section{KESIMPULAN}

Sebagian besar rumah tangga nelayan berada pada kategori kurang pangan sebesar 50,00 persen. Sisanya berada pada kategori tahan pangan 29,17 persen, rentan pangan 10,42 persen dan rawan pangan 10,42 persen. Faktor yang berpengaruh positif terhadap ketahanan pangan rumah tangga nelayan adalah pendidikan ibu rumah tangga dan pendapatan rumah tangga sedangkan faktor yang berpengaruh negatif adalah jumlah anggota rumah tangga. Upaya-upaya pemerintah meningkatkan ketahanan pangan meliputi pemantapan ketersediaan pangan, penganekaragaman pangan, pemanfaatan pekarangan, pengendalian harga pangan, pembinaan, bantuan sarana dan prasarana, program PKH dan raskin. Upaya-upaya rumah tangga untuk meningkatkan ketahanan pangan yakni dengan merubah pola makan, melakukan pekerjaan di luar usaha tangkap, berhutang dan memperkerjakan anggota rumah tangga

\section{DAFTAR PUSTAKA}

Anggraini M, Zakaria WA dan Prasmatiwi FE. 2014. Ketahanan pangan rumah tangga petani kopi di Kabupaten Lampung Barat. JIIA, 2(4):124-132 http:/jurnal.fp.unila.ac.id/ index.php/JIIA/article/download/1641/1467. [ 8 April 2018 ].

BPS [Badan Pusat Statistik] Kabupaten Tanggamus. 2017. Produksi Perikanan Kabupaten Tanggamus. Penerbit BPS Kabupaten Tanggamus.

Delly DP, Prasmatiwi FE dan Prayitno RT. 2019. Ketahanan pangan rumah tangga nelayan di Desa Sukajaya Lempasing Kecamatan Teluk Pandan Kabupaten Pesawaran. JIIA, 7(2): 141-148. http://jurnal.fp.unila.ac.id/ index.php/JIA/article/download/3373/2575. [10 Agustus 2019].
Hernanda T, Indriani Y dan Listiana I . 2013. Ketahanan pangan rumah tangga petani jagung di Kecamatan Simpang Kabupaten Ogan Komering ULU (OKU) Selatan. JIIA, 1(4):311-318.http://jurnal.fp.unila.ac.id/ind ex.php/JIA/article/view/1641/1467. [ 3 Maret 2018].

Ilham N dan Sinaga BM. 2007. Penggunaan pangsa pengeluaran pangan sebagai indikator komposit ketahanan pangan. Jurnal Sosial Ekonomi Pertanian dan Agribisnis, 7(3):213328. https://ojs.unud.ac.id/index.php/soca/ ar ticle/view/4217/3200. [10 Desember 2017].

Imron M. 2003. Kemiskinan dalam masyarakat nelayan. Jurnal Masyarakat dan Budaya, 5(1):25-41. http://jmb.lipi.go.id/index.php /jmb/article/view/259. [12 November 2017].

Indriani Y. 2015. Gizi dan Pangan. CV. Anugrah Utama Raharja (AURA). Bandar Lampung.

Kusnadi. 2002. Nelayan: Strategi Adaptsi dan Jaringan Sosial. Humaniora Utama Press. Bandung.

Kementrian Hukum dan HAM. 2012. UndangUndang Republik Indonesia Nomor 18 Tahun 2012 Tentang Pangan. https://luk.staff.ugm.ac.id/atur/UU18-2012 Pangan.pdf [ 14 Oktober 2017].

LIPI [Lembaga Ilmu Pengetahuan Indonesia]. 2012. Widyakarya Nasional Pangan dan Gizi (WNPG) X tahun 2012. Prosiding. LIPI. Jakarta.

Pumami DA, Sukarsa IK dan Gandhiadi. 2015. Penerapan regresi logistik ordinal untuk menganalisis tingkat keparahan korban kecelakaan lalu lintas Kabupaten Buleleng. Junal Matematika,4(2):5458.https://ojs.unud .ac.id/index.php/mtk/article/view/13471 [12 November 2017].

Purwaningsih Y. 2008. Ketahanan pangan:situasi, permasalahan, kebijakan dan pemberdayaan masyarakat. Jurnal Ekonomi Pembangunan, $9(1): 1 \quad$ - 27. http://mesp.fe.uns.ac.id/ media/Ketahanan\%20Pangan\%202008.pdf. [21Mei 2018].

Sugiarto DS, Sunaryanto LT dan Oetomo DS. 2003. Teknik Sampling. PT. Gramedia Pustaka Utama. Jakarta.

Yuliana P, Zakaria WA dan Adawiyah R. 2013. Ketahanan pangan rumah tangga nelayan di Kecamatan Teluk Betung Selatan Kota Bandar Lampung. JIIA,1(2):181-186. http://jurnal.fp.unila.ac.id/index.php/JIA/arti c le/view/246/245. [23 Januari 2018]. 